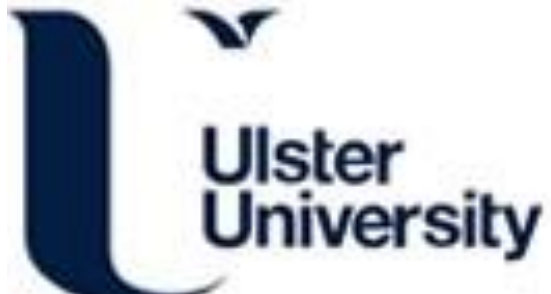

\section{The mediating influence of organisational cultural practices in successful Lean Management Implementation}

Cadden, T., Millar, K., Treacy, R., \& Humphreys, P. (2020). The mediating influence of organisational cultural practices in successful Lean Management Implementation. International Journal of Production Economics, 229, [107744]. https://doi.org/10.1016/j.jpe.2020.107744

Link to publication record in Ulster University Research Portal

\section{Published in:}

International Journal of Production Economics

Publication Status:

Published (in print/issue): 01/11/2020

DOI:

10.1016/j.ijpe.2020.107744

\section{Document Version}

Author Accepted version

\section{General rights}

Copyright for the publications made accessible via Ulster University's Research Portal is retained by the author(s) and / or other copyright owners and it is a condition of accessing these publications that users recognise and abide by the legal requirements associated with these rights.

\section{Take down policy}

The Research Portal is Ulster University's institutional repository that provides access to Ulster's research outputs. Every effort has been made to ensure that content in the Research Portal does not infringe any person's rights, or applicable UK laws. If you discover content in the Research Portal that you believe breaches copyright or violates any law, please contact pure-support@ulster.ac.uk. 


\title{
THE MEDIATING INFLUENCE OF ORGANISATIONAL CULTURAL PRACTICES IN SUCCESSFUL LEAN MANAGEMENT IMPLEMENTATION
}

\begin{abstract}
Previous research shows a low success rate for lean implementations. Few studies have considered the role that organisational culture plays in lean implementations and specifically the interaction effects of Organisational Culture and Lean Management on Operating Performance. This research examines empirically the role that Organisational Culture (OC) plays in the relationship between Lean Practices (LPs) and Operational Performance (OP) using a survey of 295 UK manufacturers. Cultural dimensions are shown to fully mediate the impact of lean management practices on Operational Performance. The findings indicate that LPs are positively associated with organisational cultures that are procedurally focused, employee oriented, structurally open, socially loose, rule driven (norm) and market oriented. In contrast, LPs are negatively associated with results-oriented and pragmatic cultures, which also carried over to the impact on operating performance. The results highlight that a procedural focus is important for lean practice integration. Moreover, LPs are shown to be positively associated with the softer dimensions of culture (i.e. employee orientation and open communication), which appear to aid initial lean integration. However, only external market orientation is associated with improved operating performance. Overall, the findings provide new insights into the contextual factors associated with successful Lean implementations.
\end{abstract}

Keywords: Lean Management, Lean Implementation, Organisational Culture, Operating performance.

\subsection{Introduction}

Shorter product life cycles, increased global competition and dynamic environments have resulted in firms placing a prioritised focus on operational strategies as a means to enhance competitive advantage (Karmarkar, 2004; cited by Hadid and Mansouri, 2014). Business improvement methodologies, specifically lean management, have been heralded as a key vehicle to achieve this advantage (Bhamu 
and Singh Sangwan, 2014; Maskell and Kennedy, 2007; Samuel et al, 2015). Lean Management is a principle founded in the east in the mid 1970's (Womack and Jones, 1996; Holweg, 2007). Yet, it was some time after that the term Lean Manufacturing entered the academic lexicon more formally through a seminal report of the implementation of what is widely known as the 'Toyota Production System' (Womack et al, 1990). Since then, much investigation has been conducted into lean management (Holweg, 2007; Samuel et al, 2015; Wiengarten et al, 2015).

Globally, academics and practitioners have been aroused by the perceived positive performance outcomes that can be achieved from lean implementation (Hadid et al, 2016; Nawanir et al, 2013).

A general consensus is that successful implementation of lean principles has the potential to eliminate Non-Value Activities (NVA) to enhance efficiency and effectiveness of a firm's operations, which in turn also delivers superior customer service (Hadid and Mansouri, 2014). However, whilst significant global attention has been paid to applying lean management techniques both by industry and academia, (Bhamu and Singh Sangwan, 2014; Maskell and Kennedy, 2007) not all implementations appear to yield the desired outcomes, such as enhanced business and firm performance (Losonci et al, 2017; Samuel et al, 2015).

It is argued in this paper that a key reason for lean implementation not achieving the desired performance outcomes is due to the organisations mismanaging and/or ignoring the cultural environment in which the firm operates (Losonci et al, 2017; Wiengarten, 2015). Researchers report reasons for this 'cultural myopia' (Cadden et al, 2013, p96) are due to organisational culture being regarded as independent; unobservable, and difficult to measure (Wiengartenet al, 2015; Cadden et al, 2015). However, given the significant influence organisational culture has on operational performance (Cartright and Cooper, 1993; Hofstede, 1996; Cadden et al, 2015), practitioners and academics alike are realising the importance of cultural management within the firm. With the practices level of culture being increasingly reported as a gateway to measuring and investigating organisational culture (Hofstede, 1996; Cadden et al, 2015). Moreover, studies are making strong references and acknowledgements of the influence of organisational culture in successful lean practice adoption 
(Badurdeen et al, 2011; Bortolotti et al, 2015). While this body of knowledge has helped deepen the understanding of the domain and paved the way for further empirical studies (Losonci et al, 2017; Bortolotti et al, 2015), the majority of these studies are conceptual or fleeting in nature or are theoretical reviews (Holweg 2007; Samuel et al, 2015).

The primary objective and key theoretical and managerial contribution of this paper therefore is to bridge this research gap (Losonci et al, 2017) through investigating the interplay between lean practices, organisational cultural practices and operational performance. The central proposition being that firms that pay attention to organisational culture in lean practices adoption are likely to see positive operational performance outcomes.

A second key contribution of this paper will be to deconstruct organisational culture into sub dimensions to provide additional insights into the key elements of culture that are relevant in embedding lean management in support of high operational performance outcomes. To date, organisational culture is largely studied at a superficial and shallow level (Losonci et al, 2017). Therefore, the central research question in this study is: "What key cultural practices need to be influenced when implementing lean management practices in order to support high operational performance outcomes?"

\subsection{Literature Review}

The literature review section is organised into three main sections: lean management, organisational culture, and operational performance. Following the literature review section, a hypothesis development section will be proposed.

\subsection{Lean Management}


The term 'lean' was first used in the 1980's as authors attempted to define the secret behind the success of Japanese manufacturing companies, the most notable being the Toyota Production System (TPS) (Bamford et al, 2015; Womack et al, 1990; Krafcik, 1988). The publication of 'The Machine that Changed the World', by Womack et al (1990) is long-established in literature as the seminal piece of work that propelled lean manufacturing into popularity (Andelkovic et al, 2016). This proposes that the customer-centric philosophy of lean is based upon five principles (define value, identify the value stream, create flow, introduce pull to customer and seek perfection) with the aim of reducing waste from the process being considered (Womack and Jones, 1996).

Since then, much has been written about lean, with each piece offering its own definition, process, philosophy, program, approach or set of principles. For example, it has been described as "a management approach” (Belekoukias et al, 2014 p.5348) and as having both strategic and operational levels (Hines et al, 2004). Indeed, it has been widely agreed that there is, in fact, no common definition of the concept (Bhamu and Singh Sangwan, 2014; Taylor et al, 2013). However, in general, the literature focuses on lean as a set of tools and techniques that improve customer value through the reduction of non-value adding activities at an operational level (Wiengarten et al, 2015; Shah and Ward, 2003), supported by a strategic organisational philosophy of improvement and wellbeing (Losonci et al, 2017, Womack and Jones, 2003, Hines et al, 2004).

Over time this has led to a number of research directions in lean management, splitting it into bundles of tools or related practices such as JIT, TQM, and human resource related processes (Bortolotti et al, 2015; Shah and Ward, 2007). The engagement of employees is also seen as a fundamental element of the lean approach (Cua et al, 2001), in the mutual and combined effort towards improved processes and quality (Wiengarten et al, 2015) and an area that until recently has gained little consideration (Taylor et al, 2013). Bhasin (2013) and Taylor et al. (2013) both emphasise the growing importance of 'human issues' and the need for companies to address these in the implementation and sustainability of lean. As a result, this research focuses on the practices related to lean management, as it is these that are most impacted by the staff using them. 
Research has started to focus on the importance of the contextual factors which surround lean implementations such as the human aspects of lean management outlined above. Further, the importance of employee involvement in achieving successful lean management implementation is being reported (Hu et al, 2015). Researchers are taking a more holistic perspective of lean implementations and directed attention to organisational culture and its impact on lean management practices (Bortolotti et al 2015; Wiengarten et al 2015). This is not surprising given many modern organisations still struggle with lean implementations and often fail to meet their desired targets (Chen and Meng 2010; Bhasin, 2013; Pearce et al, 2018). Moreover it is noted in a study by Vlachos et al (2015), that "cultural and people issues" are one of the three main reasons lean implementations fail, the others being related to leadership issues and the failure to develop a lean action plan. Hence, it is important that the role of organisational culture in lean management implementation is investigated further (Vlachos, 2015; Losonciet al, 2017; Pearce et al, 2018).

\subsection{Organisational Culture}

Organisational culture entered the academic lexicon in the late 1970's (Pettigrew, 1979). Since then, there have been many attempts to define organisational culture in a sentence, with more than 50 definitions reported (Sirmon and Lane, 2004; Cadden et al, 2015). Despite the many definitions of culture in the literature, there is a general consensus among researchers that culture relates to patterns of values and beliefs that are manifested in practices, behaviours and various artefacts shared by organisational members (Hofstede, 1980; Trice and Beyer, 1993; Pothukuchi et al, 2002). The practices level is widely recognised amongst researchers as the most visible and measurable layer for organisational culture (Cadden et al, 2015; Hofstede, 1980; Schein, 1992, 2010). For example, Fletcher, (1992) stated organisational culture as 'the underlying values, beliefs and principles of the personnel as they are expressed in the management structure and practices" (Fletcher, 1992: pg. 30). It is this general definition that this study adopts as its research lens. Verbeke (2000) argued that organizational practices are more flexible and variable because they are affected by control systems and external pressures. Further, Verbeke (2000) highlighted that organizational behaviour scholars usually use the term 
organizational practices to refer to "systematized and customary activities deemed important by the organization or its members".

Cadden et al, (2015) highlighted that culture could be conceptualized through the dimensions of results vs process; employee vs job; open vs closed; loose vs tight; normative vs pragmatic; and market vs internal. This scale of organizational practices was first put forward by Hofstede et al (1990) and later updated and validated by Verbeke (2000). This scale has recently been used in studies by Cadden et al (2015; 2013). The dimensions of organizational practices are dichotomous in that each is divided into two poles. If an organization is results-oriented, problems are shared across boundaries, functions and departments cooperate well with each other and employees contribute to business improvements. By contrast, a process-oriented organization is one in which employees adhere strictly to their own responsibilities within their own process and department with limited cooperation between departments. An employee-oriented organization is committed to personal development and education of its personnel as well as creating a good working environment for them. On the other hand, job-oriented organizations do not recognise employee achievements or contributions and highlight organizational profitability as the sole priority. An open organizational culture will encourage employees to criticize decisions and outcomes whereas a closed organization is typified by a blame culture and an aversion to public criticism. The loose-tight dichotomy resembles behaviour control versus outcome control from the organization behaviour literature. It concerns how management controls its employees. A tight organization will actively check and control employee behaviours whereas employees in a loose organization will have much more autonomy and levels of freedom. Organizations with pragmatic organizational practices are focused on meeting customer needs. They prioritise meeting results as being more important than procedures. By contrast, organizations with normative organizational practices comprehend their role in the market to be the implementation of unbreakable rules. The market-internal dichotomy reflects strategic orientation. An organization whose organizational practices are marketoriented uses information from customers and suppliers in formulating operational strategies whereas an organisation with internal organizational practices prioritises organisational efficiencies. 
To date, studies linking lean management and organisational culture are relatively rare. Moreover, the handful of studies which have examined the linkages between LPs and OC have been largely fragmented or lacking depth. For instance, aside from a study by Bortolotti et al (2015) which examined the relationship between soft lean practices and organisational culture, studies linking LPs and OC have either; (1) Constituted conceptual papers or theoretical reviews (see Erthal and Marques 2018; Lagrosen \& Largosen, 2019); (2) Examined just one aspect of culture in isolation (see Wiengarten et al, 2015), and (3) Failed to consider operational performance metrics (see Bhasin, 2013; Losonci et al, 2017). These observations have led researchers such as Losonci et al (2017) to call for research which examines the relationship between the multidimensionality of OC and the success of LP in terms of operational indicators. Therefore, by employing the cultural framework developed by Verbeke (2000) to study the relationship between LPs, OC and OP, this study aims to fill a key research gap. The next section will now consider the role operational performance plays in the lean-culture relationship.

\section{$\underline{2.3 \text { Operational Performance }}$}

As operations management $(\mathrm{OM})$ research progresses overtime, the elements which constitute operating performance (OP) also continue to evolve (Chopra et al, 2004). For instance, the adoption of Japanese production models introduced to the western world in the early 1970s and 1980s directed management and researchers alike to focus on the measurable operational outcomes of and organisation's processes, in relation to quality, speed, reliability and cost (Voss et al, 1997), as manufacturers sought to move away from the traditional mass production models which came before (Schonberger, 1982; Slack et al, 2004). Accordingly, OM studies now adopt a plethora of OP dimensions to measure these factors which include items such as delivery performance, unit cost of production and defect/scrap rates (see Bortolotti et al, 2015; Demeter et al, 2017; Onofrei et al, 2019).

A second important point to note in the context of this study however, is the observation that as new streams of research have emerged focusing on the environmental conditions in which lean may be successful in organisations, many researchers have now started to adopt a wider spectrum of OP indicators (see Gambi et al, 2015; Weingarten et al, 2015; and Onofrei et al, 2019 for examples). For 
instance, in order to fully examine the role of national and organisational collectivism in lean implementations, Weingarten et al (2015) include operational indicators outlined in Shah and Ward (2003) which relate to human and customer focused dimensions of OP such as productivity and customer satisfaction. Gambi et al (2015) also take a similar approach in their study of quality management and organisational culture. This is perhaps not surprising as production paradigms such as lean management and TQM emphasise customer value, which over time has motivated researchers to adopt more customer-oriented metrics of operating performance (Womack and Jones, 2003). Examples from previous studies include; customer satisfaction, customer complaint levels and delivery performance (see Samson and Terziovski, 1999; Shah and Ward, 2003; Rahman et al, 2010; Wiengarten, et al, 2015; Rawan et al, 2018). Therefore, in order to fully explore the impact of lean practices on organisational culture, it is imperative that operational measures consider the customer dimensions of operational performance, alongside the quality, speed and cost dimensions of OP (Shah and Ward, 2003).

\subsection{Hypothesis Development}

Key questions remain as to the role of organisational culture in successful lean implementation (Matthias and Brown, 2016; Losonci et al, 2017). In line with these observations, this section will present a set of research hypotheses grounded in Verbeke's (2000) cultural model and seek to examine how lean practices and organisational culture interact to influence operating performance.

\subsection{Lean Practices and Organisational Culture}

As companies attempt to gain advantage in more competitive and global markets the use of management initiatives, that are perceived as improving performance both operationally and financially, is increasing significantly. Many studies have provided empirical evidence of the relationship between organisational culture and performance (Nikolic et al, 2011; Prajogo and McDermott, 2011), focusing on specific management practices such as quality management (Detert et al, 2000; Narasimhan et al, 2012). Indeed, in the case of lean, several studies also identify this positive relationship (Moyano-Fuentes and 
Sacristan-Diaz, 2012). However, overall there remains a divergence of opinions within the literature in relation to the performance benefits gained using lean management techniques. In their study, Mackelprang and Nair (2010) identify that there is no consistent link between the use of lean practices and performance improvements, with some authors suggesting that less than five percent of adoptions are successful (Pay, 2008). Indeed, Mackelprang and Nair (2010) posit that there may be other factors impacting the success of lean management, one of which may be organisational culture (Losonci et al, 2017; Wiengarten et al, 2015).

While Womack et al (1990) argue that the principles of lean are universal and are applicable in all situations, it has more recently been proposed that companies implementing lean practices can and should, using Toyota as an exemplar, adjust their culture to improve the chances of lean being successful (Bhasin and Burcher, 2006). Yet, when firms attempt to implement lean, the cultural emphasis is largely ignored as it has traditionally been seen as being culturally independent (Wiengarten et al, 2015; Holweg, 2007). In a growing body of literature investigating this lean-culture relationship, it has been proposed that with organisational culture working against it, lean cannot exist (Atkinson, 2010), with some going further to suggest that those executing the day-to-day lean practices are key to its success (Kull et al, 2014). Whilst these previous studies examine cultural characteristics that support the implementation of initiatives related to lean thinking, these are usually focused on the wider practices associated with TQM (Bortolotti et al, 2015), consider culture to be a single construct (Cadden et al, 2013) and do not consider the influence the adoption of these practices may have on cultural change. Wincel and Kull (2013) argue that in fact the culture is likely to evolve along with the implementation of lean practices. It has also been suggested that by using the 'Toyota Way' as a template, this only allows for a view towards an aspirational cultural foundation, rather than a pathway to achieving it (Losonci et al, 2017) and, indeed, several authors have argued that given the different strategic objectives of firms, there may be more than one ideal culture (e.g. Detert et al, 2000) for its success. As a result, authors have begun to look into lower level dimensions and characteristics of organisational culture (e.g. Bortolotti et al, 2015; Prajogo and McDermott, 2011) to understand if some of these are more robust indicators of a successful relationship between lean and performance. 
It is highlighted by Hatch and Dyer (2004) and Losonci, et al (2017) for instance that employees tasked with specific job roles appear to develop tacit knowledge which should help employees operate specialised equipment and identify optimal equipment layouts and work routines, which in turn should contribute towards continuous improvement goals. In this sense, lean practices benefit from a process oriented culture, where roles and procedures are clearly defined and employees know exactly what is expected of them. Conversely, while the standardisation of work has important process benefits, it also reduces work autonomy, can increase monotony, and according to some commentators, leads to unlimited performance demands and stressful work (Landsbergis et al, 1999; Hines et al, 2004; Mehri, et al 2006). Therefore, it makes sense for firms to also encourage an employee centric culture alongside a process culture which encourages workforce learning, employee training (i.e. upgrading skills) and employee inclusion and welfare (Hatch and Dyer, 2004). Other important cultural factors may relate to closed or defensive cultures, where communication channels may be restricted and employees may be stigmatised for failures (Verbeke, 2000). In a defensive culture, individuals are to blame rather than the process. Moreover, mistakes or problems may be withheld from fellow employees and management inhibiting process improvement (Cadden et al, 2013; Bortolotti et al, 2015). Research shows that when employees encounter abusive supervision, they are less likely to share ideas (Kim et al, 2016) which, in turn, can derail improvement practices stipulated in lean management. Therefore, employee involvement and open communications will support the implementation of lean practices such as continuous improvement (Fullerton et al, 2014).

One of most salient tensions within lean management relates to the autonomy versus procedural dichotomy (Maalouf and Gammelgaard, 2016). However, rather than focusing on formal production processes and procedures, the loose-tight dimension of Verbeke's framework differs slightly and relates to employee behavioural standards and work habits, i.e. employee punctuality, dress codes, employee discipline and dignified behaviour (Verbeke, 2000). From a behavioural standpoint, an integral part of continuous improvement and the transfer of tacit knowledge relates to employee empowerment and workforce socialisation (Nonaka et al, 1996). Moreover, employee socialisation can take place both on the production line or away from the shop floor entirely i.e. during lunch. For example, experienced 
employees may have technical know-how in terms of repairing equipment and may leave his/her workstation to aid a new staff member. A study by Angelis et al (2011) found that task support by coworkers or team members, (an autonomous, empowered decision), helps sustain worker commitment to lean management.

Although lean management's ultimate goal is to provide increased value to the customer while simultaneously utilising fewer resources, the achievement of this goal ultimately involves adhering to an operating philosophy or ideology which defines and applies organisational standards for eliminating waste and non-value adding activities (Bhasin, 2013; Piercy and Rich, 2015). A normative culture is concerned with doing things properly from a procedural perspective (Cadden, et al 2013). Indeed, a study by Bhasin (2013), on successful lean organisations in the UK, concludes that organisations cannot simply jump to the end result and hope to achieve Toyota style results. Instead, Bhasin (2013 pg. 551) argues that lean needs be witnessed as a business philosophy; "the more you believe in its doctrine, the easier it is to transform the business and to reap the benefits".

Finally, an organisation implementing lean practices should not lose sight of the ultimate goal of delivering customer value (Womack and Jones, 2003; Maalouf and Gammelgaard, 2016). At its core, lean management is about satisfying the customer (Hines, et al 2004). Being close to the customer and observing demand changes is pivotal to pull production systems (Womack and Jones, 2003). Moreover, an external focus is also important in terms of supply chain management as external suppliers can actually affect the success of internal operating procedures in a JIT manufacturing environment (Liker and Choi, 2004).

Hence:

Hypotheses H1a- H1f: Lean Practices will positively influence organizational practices to be more process oriented rather than results-oriented (H1a); to be more employee-focused rather than jobfocused (H1b); toward a more open communication climate rather than a closed one (H1c); towards 
more loose management control rather than tight management control (H1d); to be more normative rather than pragmatic (H1e); to be more market-focused rather than internally-focused (H1f).

\subsection{Organisational Culture and Operational Performance}

Much has been written in the literature concerning the impact culture can have on performance (Amsa, 1986; Cartwright and Cooper, 1993; Flamholtz and Kannan-Narasimhan, 2005; Hofstede, 1986; Marcoulides and Heck, 1993; Schein 1990; 2010; Wilderhom and Van den berg, 1998) (See Table 1 below).

\section{TAKE IN TABLE ONE}

A commonly held view is that if an organization possesses a 'strong culture', i.e. shared values, beliefs, and behaviours, then this will result in a higher level of productivity (Denison, 1984: 1990; Lee and Yu, 2004; Marcoulides and Heck, 1993; Saffold, 1988; Yilmaz et al, 2005). Yet matching this theory to practice has proved problematic and 'fuzzy' (Mackenzie, 1986; Marcoulides and Heck, 1993; Schein, 2010). It has been argued that this is due to research focusing on one dimensional definitions of culture, and ignoring the manifestation level (practices) where culture is visible, measurable and malleable (Cadden et al, 2015; Pothukuchi et al, 2002; Schein, 1990; 2010). For example, Gambi et al (2015), found that control culture or hierarchal culture, which relies on defined procedures, is directly linked to failure prevention control i.e. preventive maintenance and quality control. It was also found that a control culture has both a positive direct and indirect effect on operational performance when matched with continuous improvement and measurement techniques (lean practices). In this environment, firms strive to reduce machine downtime ultimately leading to shorter lead times (Tersine and Hummingbird, 1995). Further, in relation to employee oriented environments, Bortolotti et al (2015) found that successful lean plants use soft lean management practices such as people development more extensively than unsuccessful lean plants, while Samson and Terziovski (1999) find that soft aspects of quality management practice i.e. HRM and leadership are stronger predictors of operating performance (i.e. 
productivity, customer satisfaction, quality and employee morale) than more technically oriented criteria.

In an open culture, employees are both aligned and actively involved in corporate strategy and employees can make suggestions to management (Bortolotti et al, 2015). Employee involvement is based on the idea that the people employed in a process have the most experience on the job and therefore can have a profound impact on strategy implementation (Hu et al, 2015). For instance, Fullerton et al (2014) find that employee involvement in lean manufacturing is positively associated with reduced set-up times, cellular manufacturing and lean efforts to improve quality.

In lean production settings, where excess inventory or production buffers are not available to counter production or quality failures, employees must have the ability and authority to make decisions (Fullerton et al, 2014). In this sense, a loose rather than tight operating culture may aid favourable employee behaviours which in turn enhances operating performance. For example, studies by Patterson et al (2004) and Birdi et al (2008) linked employee empowerment to improved productivity as empowered employees on the shop floor can make key decisions quickly and also make process improvements which reduce wasteful production steps (Shah and Ward, 2007; Birdi et al 2008). Organisations which superficially or half heartily adopt management practices will find it difficult to improve internal efficiency (DiMaggio and Powell, 1983; Lo et al, 2014).

Finally, in terms of market orientation, metrics such as customer satisfaction and the number of customer compliments also represent operating performance metrics and have been adopted in previous studies relating to lean management and operating performance (Flynn et al, 2010; Cao and Zhang, 2011). In this sense, an organisation which loses sight of the customer, loses sight of its operations. Moreover, from a relational perspective, an external facing culture is also important for developing supplier relationships which in turn can enhance JIT initiatives (Liker and Choi, 2004) therefore improving throughput time and productivity. 
Hypotheses H2a- H2f: Organizational Cultural practices that are process-oriented (H2a), employeefocused $(\mathrm{H} 2 \mathrm{~b})$, display an open communication climate (H2c), emphasize loose management control $(\mathrm{H} 2 \mathrm{~d})$, are procedurally normative $(\mathrm{H} 2 \mathrm{e})$ and market-focused $(\mathrm{H} 2 \mathrm{f})$ will have a positive impact on operating performance.

\section{TAKE IN FIGURE 1}

\subsection{Method}

Researchers are continually calling for increased use of survey research in the Operations Management discipline (Cadden et al, 2015; Forza et al, 2002). Survey research was the method chosen for this study. This was due to the objectives of the study being deductive in nature, being explanatory, and to theory test causal relationships using an a priori model. This concurs with the approach of many recent studies investigating culture and lean and who have called for further survey research within this domain (Onofrei et al (2019); Wiengarten, et al (2015).

The survey research process proposed by Forza (2002), as outlined below, has been followed in this study.

\subsection{Research Sample}

The manufacturing sector was deemed appropriate to exhibit the phenomenon of interest as per previous studies on lean management and culture (e.g. Weingarten et al, 2015; Bortolotti et al, 2015); The unit of analysis in this study is the organisation (Cousins et al, 2008). The unit of observation being the individual within the firm. A range of manufacturing types were represented in this study such as electrical/electronic, automotive, pharmaceutical, mechanical and utility.

Content validity was assured by firstly conducting an extensive review of the literature. Next, the appropriateness of the scale items was assessed using a sample of 30 manufacturing managers. Further, the questionnaire was pilot tested in a class of final year students studying Masters in Business 
Administration specializing in Operations Management and ten operations management/supply chain academics. Some additional minor scale amendment was made.

\subsection{Sampling Method}

This study was conducted in the UK. Similar to other UK studies a national database of the manufacturing sector were researched as these sectors are believed to exhibit the phenomenon of interest. The initial trawl resulted in 3234 companies across the sectors (when anomalies were removed). A random sample of 1200 companies were selected and the survey forwarded based on job role (operations manager or equivalent). It was decided to use a mail-based survey. Dillman's Total Design Method (1978) was utilized; i.e., the first survey booklet included a personalized cover letter outlining the purpose and importance of the study along with reassurance of anonymity, a specific instruction guide, and postage paid stamped addressed return envelope. Further, a management report summary of the study would be made available to the respondents. One week later a reminder postcard was forwarded, followed by reissuing of full survey packs 3 and 7 weeks after initial posting for nonrespondents.

351 respondents returned questionnaires (295 were usable). Therefore, a response of $24.6 \%$ was returned which was deemed reasonable and exceeds the level of $20 \%$ reported by Malhotra \& Grover, (1998) as an acceptable response rate in survey research.

The characteristics of the sample data returned is listed in Table 2 below

\section{TAKE IN TABLE 2}

\subsection{Measures}


Lean Practices: This scale was derived from one developed previously by Weingarten et al (2015), based on the contention that they are seen as recognised tools within the Toyota Production System (Schonberger, 2007; Womack and Jones, 1990). Equipment layout, kanban use, batch sizes and regularity of order release into manufacturing were the four items used, again on a 5 point Likert scale. The purpose of this scale was to investigate the level of implementation of hard lean practices within the organisation. All measures are given in Appendix 1.

\section{TAKE IN APPENDIX 1}

Organisational Culture: Hofstede et al's (1990) practices tool is well recognized for measuring organisational culture (Pothukuchi et al, 2002). Verbeke (2000) extended and developed this tool to ensure additional reliability and validity which were previously reported as major issues with Hofstede's (1990) version (Singh et al, 1996; cited by Verbeke, 2000). Additional benefits of this revised organisational practices tool include its empirical usage in previous supply chain culture studies (Cadden et al, 2013); therefore, providing a robust validated measurement tool.

The cultural instrument used is a 35 item, 5 point Likert scale. The 35 items are broken down into six independent dimensions to assess organisational culture at a manifested practices level these are: results versus process; employee versus job; open versus closed; tight versus loose; pragmatic versus normative; and market versus internal.

A high results score indicates an organisation that is focused on results and will deviate from set roles and responsibilities to ensure the job gets done, a low results score (indicating a high process score) that an organisation that is highly rule driven, very procedural where staff will not alter from their defined roles. A high employee score indicates the organisation cares about the individual and their personal development and growth and a high level of absorptive capacity is evident; a low employee score reflects an organisation that is very much concerned about delivering on the job with no care about 
employee development. A high open score indicates an organisation that openly espouses constructive criticism; a low open score suggests a defensive culture where a blame culture exists. A high loose score reflects a loosely controlled organisation where flexibility and autonomy are more prevalent in achieving the set objectives; a low loose score indicates an organisation that thrives on controlling its employees and how they behave. A high pragmatic score indicates an organisation that focuses on achievement; a low score indicates more focus on following standards. Finally, a high market score reflects an organisation that is market oriented and concerned about its external operating environment; a low market shows an internally-focused organisation with little or no concern for its market or operating environment.

Operational Performance Outcomes: This scale was adapted from one previously used to measure operational performance measures by Gambi et al (2015) and encompassed a 6 item, 5 point likert scale for Operational Performance. Originally developed using measures from several similar studies (Flynn et al, 2010; Cao and Zhang, 2011, Cousins et al, 2008) respondents assessed items such as productivity, customer satisfaction, unit costs, lead time, complaints and scrap levels.

\subsection{Results}

\section{TAKE IN TABLE 3}

\subsection{Model}

The conceptual model shown in Figure 1 was specified and estimated. Specifically, the Results, Employee, Open, Tight, Pragmatic, and Market variables were all regressed on the Lean management Practices. Also, the Operational Performance variables were regressed on the Results, Employee, Open, Tight, Pragmatic, and Market Practices variables. To examine the relationship between the predictor and outcome variables, an indirect model was specified. This indirect model specifies that the relationship between Lean and operational performance; is fully mediated by the remaining cultural practices and lean management practices. 


\subsection{Analysis}

The indirect model described above was specified using MPlus 6 (Muthén \& Muthén, 2010) to estimate the model parameters using maximum likelihood (ML) based on a matrix of variances and covariances; and 1000 bootstrap draws. Bollen (1989) suggests that ML estimation generates statistics that are not biased under conditions of non-normality, however may produce associated test-statistics that may not be correct. Accordingly, to examine the statistical significance of any mediated effects, bootstrapped, bias-correlated based confidence intervals are recommended (Efron and Tibshirani, 1993). This is addressed in this instance with the inclusion of specified confidence intervals that should ensure no incorrect conclusions are drawn about statistical significance.

Following the guidelines suggested by Hoyle and Panter (1995) the goodness of fit for each model was assessed using a range of fit indices including the chi-square $\left(\chi^{2}\right)$, the Tucker-Lewis index (TLI; Tucker and Lewis, 1973), and the Comparative Fit Index (CFI: Bentler, 1990). A non-significant chi-square, and values greater than .95 for the TLI and CFI are considered to reflect acceptable model fit. In addition, the Root Mean Square Error of Approximation (RMSEA: Steiger, 1990) with 90\% confidence intervals $(90 \% \mathrm{CI})$ were reported, where a value less than .05 indicates close fit and values up to .08 indicating reasonable errors of approximation in the population (Jöreskog and Sörbom, 1993). The standardized root-mean-square residual (SRMR: Jöreskog and Sörbom, 1981) has been shown to be sensitive to model mis-specification and its use recommended by $\mathrm{Hu}$ and Bentler (1995). Values less than .08 are considered to be indicative of acceptable model fit (Hu \& Bentler, 1995).

Additionally, non-response bias was tested by analysing the significant differences in the responses provided in early and late returned questionnaires. (Pearl and Fairly, 1985; Lambert and Harrington, 1990). Six of the items used in the analysis were selected at random and $\chi^{2}$ tests performed on the initial and last set of 20 responses. The significance values were well above the 0.01 level, demonstrating that there was no significant difference between early and late responses and therefore no evidence of non-response bias (Armstrong and Overton, 1977). 


\subsection{Results}

An initial test of the hypotheses was conducted using regression analysis. In Step 1 we entered the control variables sales volume and manufacturing type into the model, explaining $1 \%$ of the variance of operational performance, $\mathrm{F}(2,292)=1.772, p=0.172$. In Step 2 lean practices were added to the model, explaining $10 \%$ of the overall variance, $\mathrm{F}(3,291)=10.16, p<0.001$. After entry of the 6 dimensions of organisational culture in Step 3 the total variance explained by the model as a whole was $30 \%, \mathrm{~F}(9,285)=14.47, p<0.001$. As the control variables were not statistically significant they were not included in the SEM analysis.

\section{TAKE IN TABLE 4}

The model used all variables listed above. The descriptive statistics for all the variables in the model are presented in Table 5.

\section{TAKE IN TABLE 5}

The fit of the model was found to be acceptable $\left(\chi^{2}=2.86, \mathrm{df}=2, \mathrm{p}=.24 ; \mathrm{CFI}=.99 ; \mathrm{TLI}=.98\right.$; RMSEA $=.04 ;$ SRMR $=.01)$. The chi-square was non-significant, and the CFI, TLI, RMSEA and SRMR all met the criteria for acceptable fit. To investigate whether any of the proposed factors mediate the relationship between lean and operational performance, the regression coefficients from the specified and estimated model were examined. The regression coefficients for the direct effects of lean on the culture practices; and the direct effects of culture practices and lean management practices on operational performance are reported in Table 6.

Results presented in Table 3, show that Lean was significantly, positively related to Employee $(\beta=.93$, $\mathrm{p}<.01)$, Open $(\beta=.48, \mathrm{p}<.01)$, and Market $(\beta=.63, \mathrm{p}<.01)$, and significantly, negatively related to Results $(\beta=-.57, \mathrm{p}<.01)$, Tight $(\beta=-.37, \mathrm{p}<.01)$ and Pragmatic $(\beta=-.37, \mathrm{p}<.01)$. 
TAKE IN TABLE 6

Results presented in Table 7 , show that only Market $(\beta=.17, \mathrm{p}<.01)$ was significantly, positively associated with Operational Performance, while only Results $(\beta=-.13, p<.01)$, and Pragmatic $(\beta=$ $.27, \mathrm{p}<.05)$ were significantly, negatively associated with Operational Performance.

\section{TAKE IN TABLE 7}

In relation to the above results (Tables 6 and 7), it should be noted that the regression coefficients reported are standardised, allowing the scores on the questionnaires to be used so that they can be compared as standardised units. For example, in relation to the coefficient between Results and Operational Performance $(\beta=-.13, p<.05)$, which is a significant negative correlation; as it is standardised it can be said that if a participant's score on the Results subscale increases by 1 , it corresponds to a decrease of 0.13 in their operational performance score.

\subsection{Discussion}

The literature review highlighted that there have been very few studies which attempt to 'unpack' the interlinkages between lean practices (LPs), organisational culture (OC) and operating performance (OP). Employing Verbeke's (2000) model of organisational culture, this research sought to empirically investigate the interplay between lean implementation, organisational culture and operating performance (see figure 1).

\subsection{Hypothesis H1a-H1f: Lean Practices Relationship with Organisational cultural practices.}

Hypothesis H1a-H1f examined the relationship between lean practices and organisational culture. 
Hypothesis Hla examined the relationship between LPs on the results dimension of organisational culture. Lean management was found to be negatively related to the "results" dimension of organisational culture, thereby suggesting that the LPs are geared more towards environments which promote a process based operating culture (Cua et al, 2001). Hence, hypothesis H1a was supported. This process-oriented culture, which advocates strictly adhering to the principals of a system or philosophy, should support the process standardisation and continuous improvement goals inherent within lean management (Spear and Bowen, 1999; Cua et al 2001), whereas a results-oriented culture, which often entails undertaking extra role behaviours to achieve desired outcomes, would in fact create increased complexity and variability, potentially derailing lean practices and processes (Womack et al, 1990; Marley and Ward, 2013).

Hypothesis HIb examined the relationship between LPs and the employee dimension of organisational culture. The results found that lean implementation was positively associated with an employeeoriented culture as opposed to a "job" oriented culture. Hence, hypothesis H1b is supported. This result supports the findings of Bortolotti et al (2015), who find a human orientation is linked to high performing lean management systems. Moreover, as there has been a plethora of research studies linking traditional lean production or job-oriented methods to poor employee well-being and motivation (see Anderson-Connolly et al 2002; Parker 2003), it perhaps not surprising then that LPs are linked to an employee oriented culture which advocates both employee engagement and employee development (Bortolotti et al, 2015; Vlachos and Siachou, 2018). Additionally, the results underline the importance of appealing to the softer aspects of an organisation's culture, at least initially, as its postulated an employee orientation can embed the more technical aspects of lean implementation (i.e. continuous improvement) through organisational learning and sharing of ideas (Bortolotti, et al 2015).

Hypothesis HIc examined the relationship between LPs and the open dimension of organisational culture. The results found that LPs had a positive association with an "open" organisational culture as opposed to a "closed" or defensive organisational culture. Hence, hypothesis H1c was supported. This result suggests that the efficacy of LP's are enhanced in environments which encourage open 
communication channels. This finding is reinforced in literature as it is highlighted that an open culture facilitates both employee suggestions and constructive feedback (Forza, 1996: Naor et al, 2010; Bortolotti, et al 2015). This, in turn, facilitates a learning culture which, when combined with an engaged workforce, aids behaviours associated with continuous improvement efforts such as knowledge sharing (Forza,1996; Eldor and Harpez, 2016). Moreover, Alhuraish et al (2017), find that employee involvement is ranked as the highest critical success factor in terms of organisations which have successfully implemented lean manufacturing.

Hypothesis HId examined the relationship between LPs and the tight dimension of organisational culture. The results found that LPs are negatively related to "tight" organisational cultures. Hence, hypothesis H1d is supported. The negative relationship between LPs and tight organisational structures is not surprising as previous research suggests lean practices often require work characteristics related to job autonomy, skill utilization, and participation in decision making in order to implement LPs effectively (Yang et al, 2012). In this sense, LPs are related to organisational climates which afford a degree of personal autonomy and freedom in decision making. Additionally, research by Rodriguez et al (2016), links lean production and increased job autonomy with improved job satisfaction and operating performance. In other words, the efficacy of lean implementation is enhanced when combined with HRM practices which increase workplace autonomy.

Hypothesis Hle examined the relationship between LPs and the pragmatic dimension of organisational culture. The results find that LPs are negatively related to a "pragmatic" organisational culture. Hence hypothesis H1e is supported. The negative relationship between LP and a pragmatic culture may be explained by institutional theory. For example, within a pragmatic or achievement focused environment, there is a danger that organisations may superficially, or half heartily implement lean practices as there is a lack of adherence to traditional implementation norms (Ansari et al, 2010). In other words, organisations could neglect the key pillars of lean management such as continuous improvement initiatives or fail to acknowledge other key lean practices (Liker and Rother, 2011). 
Hence, LPs should be associated with a normative culture which advocates adherence to traditional lean tools and techniques (Bhasin and Burcher, 2006).

Hypothesis HIffinds that LPs are positively associated with a market culture as opposed to an internally focused culture. Hence, hypothesis H1F is supported. This result is expected as a market culture is a customer oriented organisational culture, which focuses on satisfying the customer (Verbeke, 2000; Losonci et al, 2017). As the ultimate goal of lean management is to create customer value, lean implementation should align with a market culture (Shah and Ward, 2003). Moreover, a market focus is also important for JIT initiatives and developing external supplier relationships (Liker and Choi, 2004). The relational view of the firm highlights organisations can achieve significant productivity benefits by developing strong supplier relationships (Kannan and Tan, 2006; Krause et al, 2007). On the other hand, an organisation that is internally focused may lose sight of the customer and their operations. Hence the findings of H1f are consistent with the principals of LM.

In summary, the findings of H1a-H1f highlight that LPs are positively associated with organisational cultures which are employee oriented, structurally open, and market facing while negatively associated with tight, results focused and pragmatic organisational cultures.

After examining the relationships between LPs and OC, a third dimension: Operating performance (OP) was added to the overall research model. The findings of the hypotheses are presented below:

\subsection{Hypothesis H2A-H2F: Organisational Cultural Practices Relationship with Operational} Performance. 
Hypothesis $H 2 a$ examined the interplay between LPs, a results culture and operating performance. The results show that the combination of LPs and a results-oriented culture have a negative impact on OP. Hence, Hypothesis $\mathrm{H} 2 \mathrm{a}$ is supported. This result is expected, as hypothesis H1a highlighted that a results focused organisation may take short-cuts in lean implementation or deviate from existing procedures, thereby increasing process complexity and thwarting operating performance (Bozarth et al, 2009, Mazzacatto et, al 2014).

Hypothesis H2b examined the interplay between LPs, employee culture and operating performance. Hypothesis $\mathrm{H} 2 \mathrm{~b}$ is rejected as there was an insignificant relationship between employee/job-oriented culture and OP. While it was shown in Hypothesis H1b that LPs are positively related to an employee focused culture, this relationship does not significantly impact operating performance. This is a surprising result, however it may be explained by the idea that while an employee oriented culture may be important for LM, (Vlachos and Siachou, 2018) and improving employee related metrics i.e. satisfaction, an employee focused culture may not impact operating performance as this requires a more process driven approach (Mazzocato et al, 2014). For example, Forza and Flippini (1998) find that employee fulfilment is not linked to operating performance metrics such as customer satisfaction (Forza and Flippini, 1998).

Hypothesis $\mathrm{H} 2 \mathrm{c}$ examined the interplay between LPs, open culture and OP. Hypothesis $\mathrm{H} 2 \mathrm{c}$ is rejected as there was an insignificant relationship between an open/closed oriented culture and OP. While the finding of hypothesis H1c finds that LPs are positively related to an "Open" culture, neither the open or closed dimensions are significantly related to operating performance. Hence, while is possible that an open culture is necessary for initially implementing LPs throughout the organisation, over time, the organisation may lose control of production methods or experience diminishing returns. Moreover, Goetsch and Davis, (2010), highlight that detractors of open culture systems suggest that practices such as employee involvement may eventually represent a loss of management control while strategic direction may be misplaced overtime. In other words, there may be a loss of alignment with operating goals (Hines et al, 2006: Goetsch and Davis, 2010). 
Hypothesis H2d examined the interplay between LPs, tight culture and OP. Hypothesis H2d is rejected as there was an insignificant relationship between loose/tight oriented cultures and OP. While the results of Hypothesis H1d highlighted that LPs where negatively associated with a "tight" organisational culture, this finding is not extended to operating performance. It can be observed that a control culture may perhaps aid OP dimensions such as cost control and productivity, offsetting the negative aspects of the lean-tight relationship outlined in the previous section (Hopp and Spearman, 2004; Wee and Wu, 2009).

Hypothesis H2e examined the interplay between LPs, a pragmatic culture and OP. Hypothesis H2e is supported as the findings indicate that LPs and a pragmatic OC are negatively related to OP. Its postulated in H1e above that as a pragmatic orientation is focused on practical ideals rather than prestated norms, there is a danger that organisations may superficially adopt lean practices based on external pressures from customers etc., (Ansari et al, 2010). Crucially, this would also have a detrimental effect on process based operating indicators such as waste reduction and lead-times, (Ansari et al, 2010 Liker and Rother, 2011). Hence the negative relationship with OP is expected.

Hypothesis $H 2 f$ examined the interplay between LPs a market oriented culture and OP. The results suggest that LP's and a market-oriented culture combine to improve OP. Hence Hypothesis H2f is supported. This is not a surprise as a LPs do not neglect market performance. On the contrary, the ultimate goal of LM is to create value for the customer and this aligns with a customer facing market orientation culture, which in turn improves operating performance dimensions. In this sense, metrics such as customer satisfaction and the number of customer compliments also represent key lean performance metrics and have been adopted in previous studies relating to lean management and operating performance (Flynn et al, 2010; Cao and Zhang, 2011). Moreover, from a relational perspective, studies have shown that organisations achieve significant productivity benefits by 
developing external supplier relationships (Kannan and Tan, 2006; Krause et al, 2007) which facilitate LP's such as JIT and lean sourcing (Liker and Choi, 2004).

In summary, the results of $\mathrm{H} 2 \mathrm{a}-\mathrm{H} 2 \mathrm{f}$ show that only the dimensions of market orientation are positively associated with operating performance. More specifically, the findings highlight that LPs and a market culture combine to improve OP. On the other hand, results oriented and pragmatic cultures were found to negatively associated with operating performance.

\subsection{Implications for theory}

Due to the varied success of lean management programs there is a growing body of literature which seeks to examine the contextual factors surrounding lean implementation (Hofer et al, 2012; Vlachos and Siachou, 2018). Missing from this debate are studies which examine the interactions between lean practices (LP) and organisational culture (OC) (Losonci et al, 2017; Zhang et al, 2017). Moreover, there have been few studies which seek to examine the interplay between LP, OC and OP. Hence, this study seeks to add new insights to the lean management-organisational culture debate.

Firstly, from an institutional perspective, the results of Hypotheses H1a-H1f suggest that organisations cannot implement LP's without considering the deeper cultural dimensions surrounding LPs. This a finding supported by Ansari (2010) and Liker and Rother (2011) who find that organisations who superficially adopt LM could experience detrimental firm performance. The findings of this study support this observation as it was found that that LPs, when adopted in Pragmatic or Results oriented cultures, negatively impacted operating performance. Its postulated that "achievement" or "results" based cultures favour outcomes over a procedural or process focus, thus crippling both lean implementation and operating performance.

Secondly, the findings contribute to the LM literature as it is shown that upon the initial implementation of lean, LPs benefit from the softer aspects of an organisation's culture (i.e. employee orientation and 
open communication lines) (Bortolotti et al, 2015), however, the findings do not extend to the operating performance dimensions. It can therefore be argued that appealing to the softer aspects of culture (i.e. employees) at least initially, is particularly important in terms of integrating the lean operating philosophy throughout the organisation. This is perhaps because it is the human element of an organisation which provides the social foundation for lean implementations. In other words, employees are key influencers of "Lean" in an organisation (Bortolotti et al 2015). Despite this however, LPs and the softer aspects of culture did not directly influence operating performance. Instead, the study finds support for the relational view of the firm, as it is found that LPs and a "Market" culture combine to influence OP. In other words, organisations implementing LP should always maintain an overarching focus on the customer (Shah and Ward, 2003) and suppliers (Liker and Choi, 2004) as a market focus was shown to improve operating performance. It is postulated that firms which build robust relationships with suppliers, will benefit from increased productivity as organisations can develop robust JIT and lean sourcing practices and respond better to changes in demand (Krause et al, 2007; Wee and $\mathrm{Wu}, 2009)$.

\subsection{Implications for management}

Based on the findings from the study, a lean-culture framework was developed based on the interplay between LPs, OC and OP. This model is outlined in Figure 1 and can help management navigate the various lean-culture relationships while also improving the efficacy of LP's in terms of operating performance. More specifically, organisations seeking to implement LM should target the softer aspects of an organisation's culture and move to engage employees whilst also maintaining open communication lines in order to fully integrate lean management practices with OC. However, management should be aware that although the soft (i.e. employee oriented) and hard (i.e. process focused) cultural dimensions discussed in this study aided lean integration, they did not combine to impact overall operating performance. Secondly, management should be wary when implementing LP's in results or pragmatic based cultures, as the results show that an overarching focus on outcomes and results, at the expense of a process focus, can stifle both lean implementation and operating 
performance. Finally, above all, in both the integration and performance domains, management should not lose sight of suppliers or the customer as LP's and an external market focus was shown to enhance operating performance.

\section{Conclusion}

Previous research estimated that that less than five percent of lean adoptions are successful (Pay, 2008) Hence, there is a need for research which explores the contextual factors surrounding lean implementation (Vlachos and Siachou, 2018). The findings of this study highlight that LPs are positively associated with organisational cultures which are procedurally focused, employee oriented, structurally open, socially loose, rule driven (norm) and market oriented. Additionally, the findings demonstrated that results-oriented, and pragmatic cultures were found to negatively associated with both cultural integration and operating performance. Most crucial of all however, is that the results show that only the market dimension is associated with improved operating performance. Hence, the study demonstrates that LP's need to be implemented in full, focusing on the softer aspects of organisational culture i.e. employee engagement, and it is ultimately in the customer domain the performance benefits of lean are most valuable. Finally, the lean implementation framework outlined in this study not only contributes key insights to both the operations management and organisational behaviour fields, but can also act as a cultural guide to management in industry who are perhaps embarking on a lean transformation. 


\section{REFERENCES}

Alhuraish, I., Robledo, C., and Kobi, A (2017), “A comparative exploration of lean manufacturing and six sigma in terms of their critical success factors", Journal of Cleaner Production, Vol. 164, pp.325337.

Amsa, P. (1986), "Organizational culture and work group behavior: an empirical study", Journal of Management Studies, Vol. 23 No. 3, pp. 347-362.

Andelkovic, A., Radosavljevic, M. and Panic, D. S. (2016), "Effects of lean tools in achieving lean warehousing". Economic Themes, Vol. 54 No. 4, pp. 517-534.

Anderson-Connolly, R, L Grunberg, E S. Greenberg, and S Moore (2002), "Is Lean Mean?: Workplace Transformation and Employee Well-Being”. Work, Employment \& Society, Vol. 6 No. 3, pp. 389-413. Angelis, J., Conti, R., Cooper, C. and Gill, C. (2011), "Building a high-commitment lean culture", Journal of Manufacturing Technology Management, Vol. 22 No. 5, pp. 569 - 586.

Ansari, S.M., Fiss „P.C., Zajac, E.J.,(2010), “Madeto fit: how practices vary as they diffuse”, Academy of Management Review, Vol. 35 No. 1, pp. 67-92.

Armstrong, J.S. and Overton, T.S. (1977), "Estimating nonresponse bias in mail surveys", Journal of Marketing Research, Vol. 14 No. 3, pp. 396-402.

Atkinson, P. (2010), “Lean is a cultural issue”. Management Services, Vol. 54 No. 2, pp. 35-41.

Badurdeen, B, Wijekoon, K, and Marksberry, P. (2011), “An analytical hierarchy process-based tool to evaluate value systems for lean transformations", Journal of Manufacturing Technology Management, Vol. 22 No. 1, pp. 46-65.

Bamford, D., Forrester, P., Dehe, B., and Leese, R.G. (2015), "Partial and iterative Lean implementation: two case studies", International Journal of Operations \& Production Management, Vol. 35 No. 5, pp. 702-727. 
Belekoukias, I., Garza-Reyes, J. A. and Kumar, V. (2014), “The impact of lean methods and tools on the operational performance of manufacturing organisations", International Journal of Production Research, Vol. 52 No. 18, pp. 5346-5366.

Bentler, P. (1990), “Comparative Fit Indexes in Structural Models", Psychological Bulletin, Vol. 107 No. 2, pp. 238-246.

Bhamu, J. and Singh Sangwan, K. (2014), "Lean manufacturing: literature review and research issues", International Journal of Operations \& Production Management, Vol. 34 No. 7, pp. 876-940.

Bhasin, S. and Burcher, P. (2006), "Lean viewed as a philosophy", Journal of Manufacturing Technology Management, Vol. 17 No. 1, pp. 56-72.

Bhasin, S. (2013), "Analysis of whether Lean is viewed as an ideology by British organizations". Journal of Manufacturing Technology Management, Vol. 24 No. 4, pp. 536-554.

Birdi, K., Clegg, C., Patterson, M., Robinson, A., Stride, C. B., Wall, T. D., \& Wood, S. J. (2008), “The impact of human resource and operational management practices on company productivity: A longitudinal study”, Personnel Psychology, Vol. 61 No. 3, pp. 467-501.

Bollen, K.A. (1989), Structural Equations with Latent Variables. John Wiley and Sons, Inc., New York. Bortolotti, T., Danese, P., Romano, P, (2013), “Assessing the impact of just-in-time on operational performance at varying degrees of repetitiveness", International journal of Production Research, Vol. 51 No. 4, pp. 1117-1130.

Bortolotti, T., Boscari, S. and Danese, P. (2015), "Successful lean implementation: organizational culture and soft lean practices”, International Journal of Production Economics, Vol. 160, pp. 182-201. Bozarth, C. C., Warsing, D. P., Flynn, B. B., Flynn, E. J. (2009), “The impact of supply chain complexity on manufacturing plant performance", Journal of Operations Management Vol. 27 No. 1, pp. $78-93$. 
Cadden, T., Marshall, D., and Cao, G. (2013), “Opposites Attract: Inter-Organisational Cultural Fit and Supply Chain Performance", Supply Chain Management: An International Journal, Vol. 18 No. 1, pp. 86-103.

Cadden, T., Marshall, D., Humphreys, P., and Yang, Y. (2015), "Old habits die hard: exploring the effect of supply chain dependency and culture on performance outcomes and relationship satisfaction", Production Planning \& Control, Vol. 26 No. 1, pp. 53-77.

Cao, M. and Zhang, Q. (2011), "Supply chain collaboration: Impact on collaborative advantage and firm performance". Journal of Operations Management, Vol. 29 No 3, pp.163-180.

Cartwright, S. and Cooper, C.L. (1993), “The role of cultural compatibility in successful organisations marriage", Academy of Management Executive, Vol. 7 No. 2, pp.57-70.

Chan, F.T.S. and Qi, H.J. (2003) "An innovative performance measurement method for supply chain management", Supply Chain Management: An International Journal, Vol. 8 No 3, pp.209-223.

Chen, L. and Meng, B. (2010). "Why Most Chinese Enterprises Fail in Deploying Lean Production", Asian Social Science, Vol, 6 No. 3 pp 52-57.

Chopra, S. Lovejoy, W. and Yano, C (2004) "Five Decades of Operations Management and the Prospects Ahead". Management Science, Vol. 50, No. 1, pp. 8-14.

Cousins, P., Lawson, B., and Squire, B. (2008), "Performance Measurement in Strategic Buyer Supplier Relationships: The Mediating Role of Socialisation Mechanisms", International Journal of Operations and Production Management, Vol. 28 No. 6, pp. 2381-2381.

Cua, K.O., McKone, K.E., and Schroeder, R.G. (2001), "Relationships between implementation of TQM, JIT, and TPM and manufacturing performance", Journal of Operations Management, Vol. 19 No. 6, pp. 675-694.

Demeter, K., Szász, L. and Boer, H. (2017), "Plant role and the effectiveness of manufacturing practices", International Journal of Operations \& Production Management, Vol. 37 No. 12, pp. 17731794. 
Denison, D. R. (1984), "Bringing corporate culture to the bottom line”, Organizational Dynamics, Vol. 13 No. 2, pp.5-22.

Denison, D. R. (1990), Corporate culture and organizational effectiveness, JohnWiley, New York.

Detert, J., Schroeder, R.G., and Mauriel, J. (2000), “A framework for linking culture and improvement initiatives in organizations", Academy of Management Review, Vol. 25 No. 4, pp. 850-863.

DiMaggio, P. J. and Powell W. (1983), "The iron cage revisited: institutional isomorphism and collective rationality in organizational fields", American Sociological Review, Vol. 48 No 2, pp. 14760.

Efron, B., and Tibshirani, R. J. (1993). An introduction to the bootstrap. Chapman \& Hall, New York. Eldor, L., and Harpaz, I. (2016), “A process model of employee engagement: the learning climate and its relationship with extra-role performance behaviours", Journal of Organisational Behaviour. Vol. 37 No. 2, pp. 213-235.

Erthal, A. and Marques, L. (2018) "National culture and organisational culture in lean organisations: a systematic review". Production Planning \& Control, Vol 29, No 8, 668-687.

Flamholtz, E. and Kannan-Narasimhan, R. (2005), "Differential impact of cultural elements on financial performance", European Management Journal, Vol. 23 No. 1, pp. 50-64.

Fletcher, B., and Jones, F. (1992), "Measuring Organisational Culture: The Cultural Audit", Managerial Auditing Journal, Vol. 7 No. 6, pp. 30-36.

Flynn, B.B., Huo, B. and Zhao, X. (2010), "The impact of supply chain integration on performance: A contingency and configuration approach", Journal of Operations Management, Vol. 28 No 1, pp. 5871.

Forza, C (1996), "Work organization in lean production and traditional plants: What are the differences?", International Journal of Operations \& Production Management, Vol. 16 No. 2, pp. 4262. 
Forza, C. and Flippini, R., (1998), "TQM impact on quality conformance and customer satisfaction: a causal model”, International Journal of Production Economics, Vol. 55 No. 1, pp. 1-20.

Fullerton R.R., Kennedy, F.A. Widener, S. K. (2014), "Manufacturing and firm performance: The incremental contribution of lean management accounting practices", Journal of Operations Management, Vol. 32 No. 7-8, pp. 414-428.

Gambi, L., Boer, H., Gerolamo, M., Jorgensen, F., and Carpinetti, L. (2015), “The relationship between organizational culture and quality techniques, and its impact on operational performance", International Journal of Operations and Production Management, Vol. 35 No. 10, pp. 1460-1484.

Goetsch, D.L. and Davis, S. (2010), Quality Management for Organizational Excellence: Introduction to Total Quality, 6th Edn, Prentice Hall, New Jersey.

Gordon, G. G. and DiTomaso, N. (1992), "Predicting corporate performance from organizational culture”, Journal of Management Studies, Vol. 29 No. 6, pp. 783-798.

Hadid, W. and Mansouri, S.A. (2014), "The lean-performance relationship in services: a theoretical model”, International Journal of Operations \& Production Management, Vol. 34 No. 6, pp. 750-785.

Hadid, W., Mansouri, S.A., and Gallear, D. (2016), “Is lean service promising? A socio-technical perspective", International Journal of Operations and Production Management, Vol. 36 No. 3, pp. 618-642.

Hatch, N., \& Dyer, J. (2004), "Human capital and learning as a source of sustainable competitive advantage", Strategic Management Journal, Vol. 25 No. 12, pp. 1155-1178.

Hines, P., Holweg, M.,and Rich, N. (2004), "Learning to evolve: a review of contemporary lean thinking", International Journal of Operations and Production Management, Vol. 24 No. 10, pp. 994 1011.

Hines, P. Francis, M and Found, P. (2006), “Towards lean product lifecycle management A framework for new product development", Journal of Manufacturing Technology Management Vol. 17 No. 7, pp. 866-887. 
Hofer, C., Eroglu, C., and Rossiter Hofer, A. (2012), "The effect of lean production on financial performance: The mediating role of inventory leanness", International Journal of Production Economics, Vol. 138 No. 2, pp. 242-253.

Hofstede, G. (1980), Culture's Consequences: International Differences in Work-Related Values, Sage, Beverly Hills.

Hofstede, G. (1986), “The usefulness of the organizational culture concept”, Journal of Management Studies, Vol. 23 No. 3, pp. 253-258.

Hofstede, G. Neuijen, B. Ohayv, D.D. and Sanders, G. (1990), "Measuring organizational cultures: a qualitative and quantitative study across twenty cases", Administrative Science Quarterly, Vol. 35 No. 2, pp. 286-316.

Hofstede, G. (1996). Cultures and organizations: Software of the mind: Intercultural cooperation and its importance for survival. McGraw Hill, New York.

Hofstede, G., Hofstede, G.J., and Minkov M. (2010), Cultures and Organisations: software of the mind (3ed.). McGraw Hill, New York.

Holweg, M. (2007), “The genealogy of lean production”, Journal of Operations Management, Vol. 25 No. 2, pp. 420-437.

Hopp, W.J. and Spearman, M.L. (2004), “To pull or not to pull: what is the question?”, Manufacturing \& service operations management, Vol. 6 No. 2, pp. 133-148.

Hoyle R.H. and Panter A.T. (1995), Writing about structural equation models in structural equation modeling: Concepts, issues, and applications. Thousand Oaks, CA.

Hu, L., and Bentler, P. M. (1995), “Evaluating model fit”, in R. H. Hoyle, Structural equation modeling: concepts, issues, and applications. Sage, Newbury Park, CA.

Hu, Q., Mason, R., Williams, S. J., and Found, P. (2015), "Lean implementation within SMEs: A literature review" Journal of Manufacturing Technology Management, Vol. 26 No. 7, pp. 980-1012. 
Jöreskog, K. G., and Sörbom, D. (1984), LISREL VI users guide (3rd ed.). Scientic Software, Moorsville, IN.

Kannan, R. and Tan, K.C. (2006) "Buyer-supplier relationships: The impact of supplier selection and buyer-supplier engagement on relationship and firm performance", International Journal of Physical Distribution \& Logistics Management, Vol. 36 No. 10, pp. 755-775.

Karmarkar, U. (2004) “Will you survive the services revolution?", Harvard Business Review, June, pp.100-107

Kim, S. L., Lee, S. and Yun, S. (2016), “Abusive supervision, knowledge sharing, and individual factors: A conservation-of-resources perspective", Journal of Managerial Psychology, Vol. 31 No. 6, pp. 1106-1120.

Krafcik, J.F. (1988), “Triumph of the lean production system”, Sloan Management Review, Vol. 30 No. 1, pp. 41-52.

Krause, D.R. Handfield, R.B. and Tyler B.B. (2007), "The relationships between supplier development, commitment, social capital accumulation and performance improvement". Journal of Operations Management, Vol. 25 No. 2, pp. 528-545.

Kull, T. J., Yan, T., Liu, Z. and Wacker, J. G. (2014) "The moderation of lean manufacturing effectiveness by dimensions of national culture: testing practice-culture congruence hypotheses", International Journal of Production Economics, Vol. 153, pp. 1-12.

Lagrosen, Y and Lagrosen, S. (2019) "Creating a culture for sustainability and quality - a lean-inspired way of working” Total Quality Management \& Business Excellence, Article in press.

Lambert, D.M. and Harrington, T.C. (1990), "Measuring nonresponse bias in customer service mail surveys", Journal of Business Logistics, Vol. 11 No. 2, pp. 5-25.

Landsbergis, P. A., Cahill, J., \& Schnall, P. (1999). "The impact of lean production and related new systems of work organization on worker health", Journal of Occupational Health Psychology, Vol. 4 No. 2, pp. 108-130. 
Lee, S. K. J. and Yu, K. (2004), "Corporate culture and organizational performance", Journal of Managerial Psychology, Vol. 19 No. 4, pp. 340.

Liker, J. K. and T. Y. Choi, (2004), "Building Deep Supplier Relationships”, Harvard Business Review, Vol. 82 No. 12, pp. 104-113.

Liker, J.K.,and Rother,M., (2011) Why Lean Programs Fail. Lean Enterprise Institute.

Lo, C.K.Y., Pagell, M., Fan, D., Wiengarten, F., and Yeung, A.C.L. (2014), "OHSAS 18001 certification and operating performance: the role of complexity and coupling", Journal of Operations Management, Vol. 32 No. 5, pp. 268.

Losonci, D., Kasa, R., Demeter, K., Heidrich, B., and Jenei, I. (2017), “The impact of shop floor culture and subculture on lean production practices", International Journal of Operations \& Production Management, Vol. 37 No.2, pp. 205-225.

Maalouf, M. and Gammelgaard, B. (2016), "Managing paradoxical tensions during the implementation of lean capabilities for improvement", International Journal of Operations \& Production Management, Vol. 36 No. 6, pp. 687-709.

Mackelprang, A.W.and Nair, A. (2010), "Relationship between just-in-time manufacturing practices and performance: a meta-analytic", Journal of Operations Management, Vol. 28 No. 4, pp.283-302. Mackenzie, K.D. (1986), Organizational design: The organizational audit and analysis technology, Ablex Publishing Corporation, Norwood, NJ.

Malhotra, M. \& Grover, V. (1998), “An assessment of survey research in POM: form constructs to theory", Journal of Operations Management, Vol. 16 No. 4, pp. 407-425.

Marcoulides, G.A. and Heck, R.H. (1993) "Organizational culture and performance: Proposing and testing a model”, Organization Science, Vol. 4 No. 2, pp. 209.

Marley, K.A. and Ward, P.T. (2013) "Lean management as a countermeasure for "Normal" disruptions", Operations Management Research, Vol. 6 No. 1-2, pp. 44-52. 
Maskell, B. and Kennedy, F. (2007), "Why do we need lean accounting and how does it work?", Journal of Corporate Accounting and Finance, Vol. 18 No. 3, pp. 59-73.

Matthias, O. and Brown, S. (2016), "Implementing operations strategy through Lean processes within health care: The example of NHS in the UK", International Journal of Operations \& Production Management, Vol. 36 No. 11, pp. 1435-1457.

Mazzocato, P., Thor J., Bäckman, U. Brommels, M., Carlsson J., Jonsson, F, Magnus H. and

Mehri, D. (2006) “The Darker Side of Lean: An Insider's Perspective on the Realities of the Toyota Production System”, Academy of Management Perspectives, Vol. 20 No. 2, pp. 21-42.

Moyano-Fuentes, J. and Sacristán-Díaz, M. (2012), "Learning on lean: a review of thinking and research", International Journal of Operations and Production Management, Vol. 32 No. 5, pp. 551582.

Muthén, L.K. and Muthén, B.O. (2010), Mplus User's Guide. 6ed Los Angeles, CA.

Naor, M., Linderman, K. and Schroeder, R. (2010), "The globalization of operations in eastern and western countries: unpacking the relationship between national and organizational culture and its impact on manufacturing performance", Journal of Operations Management, Vol. 28 No. 3, pp. 194-205.

Narasimhan, R, Kull, T.J., and Nahm, A. (2012), “Alternative relationships among integrative beliefs, time-based manufacturing and performance", International Journal of Operations and Production Management, Vol. 32 No. 4, pp. 496-524.

Nawanir, G. Teong, K.T., and Othman, S.N. (2013), "Impact of lean practices on operations performance and business performance: some evidence from Indonesian manufacturing companies", Journal of Manufacturing Technology Management, Vol. 24 No. 7, pp. 1019-1050.

Nikolic, M., Saciv, M., Cockalo, D., Vukonjanski, J., and Jovanovic, D. (2011), "The impact of organizational culture on economic indices-a study in Serbian companies", African Journal of Business Management, Vol. 5 No. 11, pp. 4622-4635. 
Nonaka, I., Takeuchi, H., and Umemoto, K. (1996), “A theory of organizational knowledge creation”, International Journal of Technology Management, Vol. 11 No. 7-8, pp. 833.

Onofrei, G., Prester, J., Fynes, B., Humphreys, P., and Wiengarten, F. (2019) 'The relationship between investments in lean practices and operational performance: Exploring the moderating effects of operational intellectual capital', International Journal of Operations \& Production Management, Vol 39, No 3, pp, 406-428.

Parker S.K. (2003), "The Longitudinal Effects of Lean Production on Employee Outcomes and the Mediating Role of Work Characteristics", Journal of Applied Psychology, Vol. 88 No. 4, pp. 620-634.

Patterson, G.M., West, A.M., \& Wall, D.T. (2004), "Integrated manufacturing, empowerment, and company performance", Journal of Organizational Behaviour, Vol. 25 No. 5, pp. 641-665.

Pay, R. (2008), "Everybody's jumping on the lean bandwagon, but many are being taken for a ride", Industry Week, May.

Pearce, A., Pons, D. and Neitzert, T. (2018) "Implementing lean-Outcomes from SME case studies" Operations Research Perspectives, Vol 5, pp. 94-104.

Pearl, D.K. and Fairley, D. (1985), “Testing for the potential for nonresponse bias in sample surveys", The Public Opinion Quarterly, Vol. 49 No. 4, pp. 553-560.

Pettigrew, A. (1979), “On studying organizational cultures”. Administrative Science Quarterly, Vol. 24 No. 4, pp. 570-581.

Piercy, N and Rich, N. (2015), "The relationship between lean operations and sustainable operations", International Journal of Operations \& Production Management, Vol. 35 No. 2, pp. 282-315.

Pothukuchi, V. K., Damanpour, F., Choi, J., Chen, C., and Park, S.H. (2002), "National and Organisational Culture Differences and International Joint Venture Performance", Journal of International Business Studies, Vol. 33 No. 2, pp. 243-265. 
Prajogo, D. and McDermott, C. (2011), “The relationship between multidimensional organizational culture and performance", International Journal of Operations and Production Management, Vol. 31 No. 7, pp. 712-735.

Rahman S, Laosirihongthong, T. and Sohal, A.S. (2010) "Impact of lean strategy on operational performance: a study of Thai manufacturing companies" Journal of Manufacturing Technology Management, Vol. 21 No. 7, pp. 839-852.

Rawan, A. S., Sweis, R. J., and Firas Izzat, M. S. (2018), "Investigating the impact of hard total quality management practices on operational performance in manufacturing organizations". Benchmarking, Vol 25, No 7. pp. 2040-2064.

Rodríguez, D., Buyens, D., Van Landeghem, H. and Lasio, V. (2016), “Impact of Lean Production on Perceived Job Autonomy and Job Satisfaction: An Experimental Study", Human. factors and ergonomics in manufacturing and service industries, Vol. 26 No 2, pp. 159-176.

Saffold, G. S., III (1988), "Culture traits, strength and organizational performance: M", Academy of Management. The Academy of Management Review, Vol. 13 No. 4, pp. 546.

Samson, D. and Terziovski, M. (1999), "Reporting for success: the Baltimore and Ohio railroad and management information”, Business and Economic History, Vol. 28 No. 2, pp. 235-254.

Samuel, D., Found, P., and Williams, S.J. (2015), "How did the publication of the book The Machine That Changed The World change management thinking? Exploring 25 years of lean literature", International Journal of Operations \& Production Management, Vol. 35 No. 10, pp. 1386-1407

Schein, E. (1990), “Organizational culture”, American Psychologist, Vol. 45, No. 2, pp. 109-119.

Schein, E.H. (1992), Organisational Leadership \& Culture. 2ed. Jossey-Bass, San Francisco.

Schein, E.H. (2010), Organisational Leadership \& Culture. 4ed. Jossey-Bass, San Francisco.

Schonberger, R. J., (1982). "Japanese Manufacturing Techniques: Nine hidden lessons in simplicity”. The Free Press, New York. 
Schonberger, R.J. (2007), "Japanese production management: an evolution - with mixed success", Journal of Operations Management, Vol. 25 No. 2, pp. 403-419.

Shah, R. and Ward P.T. (2003), "Lean manufacturing: context, practice bundles, and performance", Journal of Operations Management, Vol. 21 No. 2, pp. 129-149.

Shah, R. and Ward, P.T. (2007), "Defining and Developing Measures of Lean Production", Journal of Operations Management, Vol. 25 No. 4, pp. 785-805.

Singh, J., Verbeke, W., \& Rhoads, G. K. (1996). Do organizational practices matter in role stress processes? A study of direct and moderating effects for marketing-oriented boundary spanners. Journal of Marketing, Vol 60 No 3, pp. 69-86.

Sirmon, D. G., and Lane, P.J. (2004), "A Model of Cultural Differences and International Alliance Performance”, Journal of International Business Studies, Vol. 35 No. 4, pp. 306-319.

Slack, N. and Lewis, M and Bates, H. (2004),"The two worlds of operations management research and practice", International Journal of Operations \& Production Management, Vol, 24, No 4, pp. 372 387.

Spear, S., and Bowen, H., (1999), "Decoding the DNA of the Toyota Production System", Harvard Business Review, Vol. 77 No. 5, pp. 96-106.

Steiger, J. H. (1990), "Structural model evaluation and modification: an interval estimation approach", Multivariate Behavioural Research, Vol. 25 No 2, pp. 173-180.

Taylor, A., Taylor, M. and McSweeney, A. (2013) "Towards greater understanding of success and survival of lean systems", International Journal of Production Research, Vol. 51 No. 22, pp. 66076630.

Tersine, R.J., Hummingbird, E.A. (1995), "Lead-time reduction: the search for competitive advantage", International Journal of Operations \& Production Management, Vol. 15 No. 2, pp. 8-18

Trice, H. M., \& Beyer, J. M. (1993). The cultures of work organizations, Prentice-Hall, Inc., Englewood Cliffs, NJ, US. 
Tucker, L. R., and Lewis, C. (1973), “A Reliability Coefficient for Maximum Likelihood Factor Analysis", Psychometrika, Vol. 38 No 1, pp. 1-10.

Verbeke, W. (2000), “A revision of Hofstede et al's (1990) organizational practices scale”, Journal of Organizational Behavior, Vol. 21 No. 5, pp. 587-602.

Vlachos (2015) “Applying Lean thinking in the Food Supply Chains: A Case Study. Production, Planning and Control, Vol. 26, No. 16, pp. $1351-1367$.

Vlachos, I and Siachou, E. (2018), “An empirical investigation of workplace factors affecting lean performance", International Journal of Productivity and Performance Management, Vol. 67 No. 2, pp. 278-296.

Voss, C., Ahlstrom, Par., and Blackmon, K. (1997), "Benchmarking and operational performance: some empirical results", International Journal of Production and Operations Management, Vol. 17 No.10, pp. 1046-1058.

Wee, H.M and Wu, S. (2009), "Lean supply chain and its effect on product cost and quality: a case study on Ford Motor Company", Supply Chain Management: An International Journal, Vol. 14 No. 5, pp. 335-341,

Wiengarten, F., Gimenez, C., Fynes, B and Ferdows, K (2015), "Exploring the importance of cultural collectivism on the efficacy of lean practices: Taking an organisational and national perspective", International Journal of Operations and Production Management, Vol. 35 No. 3, pp. 370-391.

Wilderom, C. P. M. and Van den Berg, P. T. (1998, August), A test of the leadershipcultureperformance model within a large Dutch financial organization, Paper presented at the annual meeting of the Academy of Management, San Diego, CA.

Wincel, J. and Kull, T. (2013), People, Process, and Culture: Lean Manufacturing in the Real World. CRC Press, Boca Raton.

Womack, J.P., Jones, D.T., and Roos, D. (1990), The Machine that Changed the World: The Story of Lean Production. Rawson Associates, New York. 
Womack, J. P. and D. T. Jones (1996), Lean Thinking. Simon \& Schuster, New York.

Womack, J.P. and Jones, D.T. (2003), Lean Thinking: Banish Waste and Create Wealth in Your Corporation. Simon \& Schuster Inc., New York.

Yang, C., Yeh, T., \& Yang, K. (2012), “The implementation of technical practices and human factors of the toyota production system in different industries", Human Factors and Ergonomics in Manufacturing \& Service Industries, Vol. 22 No. 6, pp. 541-555.

Yilmaz, C., Alpkan, L., and Ergun, E. (2005), "Cultural determinants of customer- and learningoriented value systems and their joint effects on firm performance". Journal of Business Research, Vol. 58 No. 10, pp. 1340-1352.

Zhang, L., Narkhede, B.E., and Chaple, A.P. (2017), "Evaluating lean manufacturing barriers: an interpretive process", Journal of Manufacturing Technology Management, Vol. 28 No. 8, pp. 10861114. 
Table 1: Organizational Culture and Performance Linkage.

\begin{tabular}{|c|c|c|c|}
\hline Reference & $\begin{array}{l}\text { Organizations } \\
\text { Involved }\end{array}$ & $\begin{array}{l}\text { Respondents } \\
\text { Involved }\end{array}$ & Contribution to Culture-Performance knowledge \\
\hline $\begin{array}{l}\text { Yilmaz et al } \\
(2005)\end{array}$ & $\begin{array}{l}134 \\
\text { manufacturing } \\
\text { firms in Turkey } \\
\text { across } 17 \\
\text { different } \\
\text { industries }\end{array}$ & $\begin{array}{l}1349 \\
\text { respondents - } \\
\text { both } \\
\text { management } \\
\text { and employee } \\
\text { level }\end{array}$ & $\begin{array}{l}\text { Collectivism when moderated via a strong culture } \\
\text { results in improved qualitative and quantitative } \\
\text { performance }\end{array}$ \\
\hline $\begin{array}{l}\text { Flamholtz and } \\
\text { Kannan- } \\
\text { Narasimhan, } \\
(2005)\end{array}$ & $\begin{array}{l}20 \text { divisions } \\
\text { within U.S based } \\
\text { medium sized } \\
\text { enterprise } \\
\text { responsible for } \\
\text { parts } \\
\text { manufacture for } \\
\text { automotive } \\
\text { industry }\end{array}$ & 702 respondents & $\begin{array}{l}\text { Found direct relationship between Customer focus, } \\
\text { Corporate citizenship, performance standards, } \\
\text { identification with the company and EBIT, and indirect } \\
\text { relationship between both human resource practices and } \\
\text { organizational communication with performance. }\end{array}$ \\
\hline $\begin{array}{l}\text { Lee and } \mathrm{Yu} \\
(2004)\end{array}$ & $\begin{array}{l}3 \text { Manufacturing, } \\
4 \text { Hospitals, and } \\
3 \text { Insurance }\end{array}$ & $\begin{array}{l}\text { Random sample } \\
\text { of } 7 \text { staff from } \\
\text { top management } \\
\text { in each firm }\end{array}$ & $\begin{array}{l}\text { Cultural strength and Supportiveness related to net } \\
\text { profit, value strength related to return on assets in } \\
\text { Manufacturing firms, cultural strength and innovation } \\
\text { related to growth of business in Insurance industries, } \\
\text { and team and task orientation and practice strength } \\
\text { related to staff turnover rates in hospitals }\end{array}$ \\
\hline $\begin{array}{l}\text { McHugh et al } \\
(2003)\end{array}$ & $\begin{array}{l}2 \text { divisions of } \\
\text { same firm }\end{array}$ & $\begin{array}{l}\text { Stratified } \\
\text { random sample } \\
\text { of } 87 \text { employees } \\
\text { across a range of } \\
\text { levels }\end{array}$ & $\begin{array}{l}\text { Found a lack of cultural alignment resulted in sub } \\
\text { optimal financial performance for the supplier }\end{array}$ \\
\hline $\begin{array}{l}\text { Pothukuchi et } \\
\text { al (2002) }\end{array}$ & $\begin{array}{l}21 \text { Indian } \\
\text { partners and } \\
\text { partners from } 21 \\
\text { other countries }\end{array}$ & $\begin{array}{l}\text { Structured } \\
\text { interviews with } \\
4 \text { executives in } \\
\text { each firm }\end{array}$ & $\begin{array}{l}\text { Found organizational culture has greater impact on } \\
\text { performance dimensions such as satisfaction, } \\
\text { competitiveness and efficiency than National culture }\end{array}$ \\
\hline $\begin{array}{l}\text { Wilderom \& } \\
\text { Van den Berg } \\
\text { (1998) }\end{array}$ & $\begin{array}{l}58 \text { divisions of a } \\
\text { large Dutch bank }\end{array}$ & $\begin{array}{l}\text { A survey of } \\
1.950 \\
\text { employees }\end{array}$ & $\begin{array}{l}\text { Huge differences between perceived and preferred } \\
\text { organizational practices has a greater impact on } \\
\text { performance, than smaller differences }\end{array}$ \\
\hline Saxton (1997) & $\begin{array}{l}\text { A study of } 8 \\
\text { countries across } \\
\text { the globe. } 98 \\
\text { partnerships in } \\
\text { the Chemicals }\end{array}$ & $\begin{array}{l}98 \text { respondents - } \\
\text { One from each } \\
\text { firm. }\end{array}$ & $\begin{array}{l}\text { Constructs such as reputation, prior relationships, and } \\
\text { shared decision making all linked to satisfaction }\end{array}$ \\
\hline
\end{tabular}




\begin{tabular}{|c|c|c|c|}
\hline & $\begin{array}{l}\text { and Allied } \\
\text { product } \\
\text { industries. }\end{array}$ & & \\
\hline Koene (1996) & $\begin{array}{l}50 \text { company- } \\
\text { owned Dutch } \\
\text { supermarket } \\
\text { stores of a large } \\
\text { retail chain }\end{array}$ & $\begin{array}{l}\text { A survey of } \\
1,228 \\
\text { employees } \\
\text { framed around } \\
\text { Hofstede's } \\
\text { practices } \\
\text { questionnaire }\end{array}$ & $\begin{array}{l}\text { Employee orientation and openness impact } \\
\text { performance through communication variables. }\end{array}$ \\
\hline $\begin{array}{l}\text { Petty et al. } \\
(1995)\end{array}$ & $\begin{array}{l}12 \text { service units } \\
\text { within a U.S. } \\
\text { firm in the } \\
\text { electric utility } \\
\text { industry }\end{array}$ & $\begin{array}{l}\text { A survey of } 832 \\
\text { employees }\end{array}$ & $\begin{array}{l}\text { The greater the teamwork the greater the performance } \\
\text { outcomes }\end{array}$ \\
\hline $\begin{array}{l}\text { Denison \& } \\
\text { Mishra (1995) }\end{array}$ & $\begin{array}{l}764 \text { firms of } \\
\text { differing sizes in } \\
\text { five different } \\
\text { U.S. industries }\end{array}$ & $\begin{array}{l}\text { A survey of } 746 \\
\text { senior } \\
\text { management }\end{array}$ & $\begin{array}{l}\text { Stable elements such as mission and consistency leads } \\
\text { to increased performance in large organisations. } \\
\text { Being flexible and adaptable leads to increased sales } \\
\text { growth (Market share and sales volumes) } \\
\text { Shared values (such as mission) leads to increase in } \\
\text { return on assets }\end{array}$ \\
\hline $\begin{array}{l}\text { Marcoulides } \\
\text { \& Heck } \\
(1993)\end{array}$ & $\begin{array}{l}\text { A study of } 26 \\
\text { varying } \\
\text { organisations } \\
\text { within US }\end{array}$ & $\begin{array}{l}\text { A survey of } 392 \\
\text { employees }\end{array}$ & $\begin{array}{l}\text { Each cultural construct has an impact on performance, } \\
\text { either directly or indirectly }\end{array}$ \\
\hline $\begin{array}{l}\text { Kotter \& } \\
\text { Heskett } \\
(1992)\end{array}$ & $\begin{array}{l}\text { A study of } 207 \\
\text { American firms } \\
\text { from across } 22 \\
\text { industries }\end{array}$ & $\begin{array}{l}\text { A survey of } 600 \\
\text { senior } \\
\text { management }\end{array}$ & $\begin{array}{l}\text { The strength of culture has a direct impact on economic } \\
\text { performance }\end{array}$ \\
\hline $\begin{array}{l}\text { Gordon \& } \\
\text { DiTomaso } \\
(1992)\end{array}$ & $\begin{array}{l}\text { A study } \\
\text { conducted in } 11 \\
\text { insurance } \\
\text { companies in the } \\
\text { US }\end{array}$ & $\begin{array}{l}\text { A survey of } 850 \\
\text { management }\end{array}$ & $\begin{array}{l}\text { Culture strength and adaptability have a direct influence } \\
\text { on short-term performance. }\end{array}$ \\
\hline $\begin{array}{l}\text { Calori \& } \\
\text { Sarnin (1991) }\end{array}$ & $\begin{array}{l}\text { A study of } 5 \\
\text { French firms }\end{array}$ & $\begin{array}{l}280 \text { senior and } \\
\text { middle } \\
\text { management }\end{array}$ & $\begin{array}{l}\text { Strength of culture, including values and practices lined } \\
\text { to growth but to a lesser extend profitability }\end{array}$ \\
\hline $\begin{array}{l}\text { Denison } \\
(1990)\end{array}$ & $\begin{array}{l}\text { A study of } 34 \\
\text { large American } \\
\text { organisations }\end{array}$ & $\begin{array}{l}\text { A survey of } \\
43,747 \\
\text { employees }\end{array}$ & $\begin{array}{l}\text { Involvement and consistency are positively related to } \\
\text { short -term performance, but only involvement is } \\
\text { related to long term performance }\end{array}$ \\
\hline
\end{tabular}




\begin{tabular}{|l|l|l|l|}
\hline & $\begin{array}{l}\text { from across 25 } \\
\text { industries }\end{array}$ & & \\
\hline $\begin{array}{l}\text { Peters and } \\
\text { Waterman }\end{array}$ & $\begin{array}{l}\text { A study of 43 } \\
\text { companies from }\end{array}$ & & $\begin{array}{l}\text { Strong cultures was positively related to increased } \\
\text { 6 different } \\
\text { industries }\end{array}$ \\
& & \\
\hline
\end{tabular}

Table 2: Profile of Respondents

\begin{tabular}{|l|l|l|}
\hline Manufacturing Sector by Type & N & Percentage \\
\hline Automotive \& aerospace & 27 & 9 \\
\hline Chemical \& pharmaceutical & 43 & 15 \\
\hline Electrical/electronic & 12 & 4 \\
\hline Food & 31 & 11 \\
\hline Mechanical & 28 & 9 \\
\hline Utility & 71 & 24 \\
\hline Textile goods & 74 & 25 \\
\hline Others & 9 & 3 \\
\hline
\end{tabular}

\begin{tabular}{|l|l|l|}
\hline Number of Employees & N & Percentage \\
\hline $1-50$ & 33 & 11 \\
\hline $51-100$ & 21 & 7 \\
\hline $100-500$ & 52 & 18 \\
\hline $500-1000$ & 24 & 8 \\
\hline $1000+$ & 164 & 56 \\
\hline
\end{tabular}

\begin{tabular}{|l|l|l|}
\hline Business Unit Sales Volume & N & Percentage \\
\hline Under £1M & 17 & 6 \\
\hline$£ 1 \mathrm{M}-£ 10 \mathrm{M}$ & 30 & 10 \\
\hline$£ 11 \mathrm{M}-£ 50 \mathrm{M}$ & 53 & 18 \\
\hline$£ 51 \mathrm{M}-£ 100$ & 23 & 8 \\
\hline Over $£ 100 \mathrm{M}$ & 172 & 60 \\
\hline
\end{tabular}


Table 3: Reliability of the scores of each of the scales used

\begin{tabular}{lc}
\hline \multicolumn{1}{c}{ Scale/Variable } & Cronbach's Alpha $(\boldsymbol{\alpha})$ \\
\hline Process (4 items) & .70 \\
Employee (8 items) & .85 \\
Open (4 items) & .73 \\
Loose (7 items) & .74 \\
Norm (4 items) & .71 \\
Market (6 items) & .82 \\
Lean Practices (5 items) & .72 \\
Operational Performance (6 items) & .81 \\
\hline
\end{tabular}

Table 4: Descriptive Statistics for the specified model

\begin{tabular}{lccccc}
\hline & $\begin{array}{c}\text { Scale Score } \\
\text { Range }\end{array}$ & $\begin{array}{c}\text { Min. } \\
\text { Reported } \\
\text { Score }\end{array}$ & $\begin{array}{c}\text { Max. } \\
\text { Reported } \\
\text { Score }\end{array}$ & Mean & St. Dev \\
\hline Process & $4-20$ & 4 & 16 & 9.00 & 2.81 \\
Employee & $8-40$ & 8 & 40 & 29.34 & 6.03 \\
Open & $4-20$ & 4 & 20 & 13.42 & 3.33 \\
Loose & $7-35$ & 7 & 32 & 17.68 & 4.97 \\
Norm & $4-20$ & 7 & 20 & 15.78 & 2.69 \\
Market & $6-30$ & 11 & 30 & 22.72 & 4.48 \\
Lean Practices & $5-25$ & 5 & 25 & 15.64 & 4.72 \\
Operational & $6-30$ & 10 & 30 & 20.34 & 3.74 \\
Performance & & & & & \\
\hline
\end{tabular}

Table 5: Standardised Regression Co-efficients (Standard Error) for direct effects

\begin{tabular}{lcccccc}
\hline & Results & Employee & Open & Tight & Pragmatic & Market \\
\hline Lean & $-.57(.10)^{* *}$ & $.93(.12)^{* *}$ & $.48(.06)^{* *}$ & $-.37(.11)^{* *}$ & $-.37(.05)^{* *}$ & $.63(.09)^{* *}$ \\
& & & & & & \\
\hline${ }^{*} \mathrm{p}<.05$ & & & & & & \\
$* * \mathrm{p}<.01$ & & & & & &
\end{tabular}


Table 6: Standardised Regression Co-efficients (Standard Error) for the direct effects of proposed mediators on outputs

\begin{tabular}{lc}
\hline & $\begin{array}{c}\text { Operational } \\
\text { Performance }\end{array}$ \\
\hline Results & $-.13(0.5)^{* *}$ \\
Employee & $.05(.05)$ \\
Open & $.10(.09)$ \\
Tight & $-.07(.04)$ \\
Pragmatic & $-.27(.11)^{*}$ \\
Market & $.17(.06)^{* *}$ \\
\hline $\begin{array}{l}* \mathrm{p}<.05 \\
* * \mathrm{p}<.01\end{array}$
\end{tabular}


Verbeke practices questionnaire

At my work:

Degree of agreement

Strongly Disagree

Strongly Agree

Process

1.

When confronted with problems, the people in a department

are:

Regularly being helped by people of other departments

$1-2-3-4-5$

2 The tasks of employees that are absent are:

Regularly taken over by colleagues

$1-2-3-4-5$

3 Requests from other departments are:

Carried out even if the correct formal procedures have not been followed

$1-2-3-4-5$

4 On special projects, there is:

A lot of cooperation between the various departments involved

$1-2-3-4-5$

5 The employees do their jobs:

Using flexible approaches based loosely on the suggested methods of the managers

$1-2-3-4-5$

\section{Employee}

With respect to people who do not feel too happy about their job, but who still perform well:

New possibilities are being investigated for them to work on

$1-2-3-4-5$

7

Whenever an employee is ill, or when something has

happened in his/her personal life:

Managers ask about their problems with interest

$1-2-3-4-5$

Employees are encouraged to take courses and to go to

seminars and conferences to help their self development

$1-2-3-4-5$

9

If there are personal conflicts between employees within a department:

The managers will attempt to solve these problems

$1-2-3-4-5$ 
At my work:

Degree of agreement

Strongly Disagree Strongly Agree

10 With respect to birthdays, marriages and births, my manager:

Shows personal interest

$1-2-3-4-5$

11 In matters that directly involve them, employees:

Usually have a say

$1-2-3-4-5$

12 My manager compliments employees on work well done:

$1-2-3-4-5$

Senior management ensure my job doesn't become too pressurized:

$1-2-3-4-5$

Open

14 If a manager has a criticism of an employee:

$\mathrm{He} / \mathrm{she}$ discusses it openly with them

$1-2-3-4-5$

15 Employees express any criticisms of management:

Directly to the management

$1-2-3-4-5$

16 At my work:

Employees are asked for constructive criticism to help their managers performance

$1-2-3-4-5$

17 The mistakes of colleagues are:

Personally discussed with him/her

$1-2-3-4-5$

Tight

18 Managers do not always check if the employees are working:

$1-2-3-4-5$

If one is a little late for an appointment with the manager, he/she will not be rapped on his/her knuckles:

$1-2-3-4-5$

If an employee goes to the dentist during working hours, there is no checking on how long he/she stays away:

$1-2-3-4-5$

21

Concerning the employees' expenses, the costs do not have to be specified in detail

$1-2-3-4-5$ 
At my work:

Degree of agreement

Strongly Disagree

Strongly Agree

22

If an employee is $\mathbf{1 5}$ minutes late for work, but goes on for an

extra 15 minutes at the end of the day:

$\mathrm{He} /$ she would not be called to account

$1-2-3-4-5$

23 The number and duration of the breaks employees take:

Are rarely checked by the managers

$1-2-3-4-5$

24 If an employee has to go to an important appointment

$\mathrm{He} / \mathrm{she}$ does not have to convince the manager of the

importance of the appointment

$1-2-3-4-5$

Norm

25

In my organization major emphasis is on meeting customer needs:

26

Results are more important than procedures:

27

28

29

I believe where I work actively honours its ethical

responsibilities:
$1-2-3-4-5$

$1-2-3-4-5$

$1-2-3-4-5$

$1-2-3-4-5$

$1-2-3-4-5$

Market

30 The satisfaction of the customer is:

Measured regularly

$1-2-3-4-5$

31 Services provided by partner agencies are:

Reported in detail to everyone

$1-2-3-4-5$

32 Customers' preferences are investigated thoroughly:

$1-2-3-4-5$

33 The organization provides services that:

Meet the needs of the various target groups

$1-2-3-4-5$

34 The future needs of customers are: 
At my work:

Discussed extensively with the various departments

35

In talks with customers, people

Try to find out about the future needs of the customers
Degree of agreement

Strongly Disagree Strongly Agree

$1-2-3-4-5$

$1-2-3-4-5$ 


\section{Lean practices questionnaire}

Please assess the following practices based on your own organization:

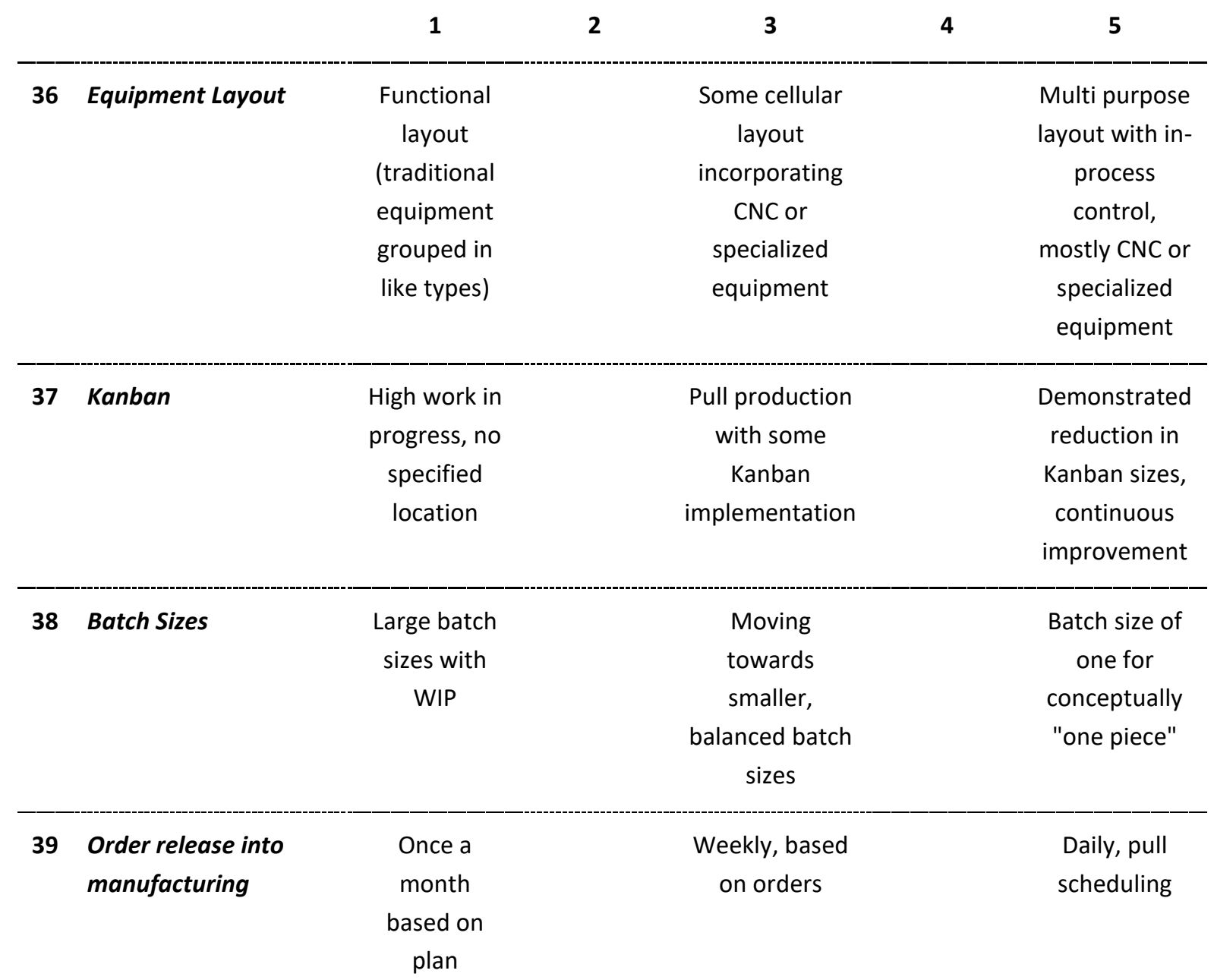




\section{Organisational performance questionnaire}

Operational Performance

Please assess the following performance measure based on your own organization:

Consistently Decreasing

Consistently Increasing

40 Productivity

$1-2-3-4-5$

Sometimes meets expectations

Exceed Expectations

41 Customer Satisfaction

$1-2-3-4-5$

Consistently Increasing

Consistently Decreasing

42 Unit cost (of manufacture)

$1-2-3-4-5$

$43 \quad$ Lead time

$1-2-3-4-5$

$44 \quad$ Number of customer complaints

$1-2-3-4-5$

45 Scrap, rework and defects

$1-2-3-4-5$ 